\title{
PENGARUH ERA DIGITAL TERHADAP PERKEMBANGAN BAHASA ANAK
}

\author{
Puji Rahayu \\ Sekolah Tinggi Agama Islam Nahdhotul Ulama (STAINU) Kotabumi Lampung \\ e-mail:Puji.Rahayuzati@gmail.com
}

\begin{abstract}
Language development is an indicator of development. $80 \%$ of developmental disorders are caused by lack of stimulation. Utilization Interactive media (digital) is one of the stimulations in this digital era. Interactive media is an audio-visual media that is expected to improve children's language skills. This media can increasevocabularies, phonation and the child's ability to understand colors, numbers and discourse / text.
\end{abstract}

Keywords: Digital Era, Development And Children's Language

\begin{abstract}
Abstrak
Perkembangan bahasa merupakan indikator dari perkembangan. $80 \%$ gangguan perkembangan disebabkan oleh kurangnya stimulasi. Pemanfaatan Media interaktif (digital) merupakan salah satu stimulasi di eradigitalini. Media interaktif merupakan media audio visual yang diperkirakan dapat meningkatkan kemampuan bahasa anak. Media inidapatmeningkatakankosa kata,fonasiserta kemampuan anak untuk memahami warna, angka dan wacana/teks.
\end{abstract}

Kata kunci : era digital, perkembangan, dan bahasa anak.

\section{Pendahuluan}

Perkembangan teknologi pada

zaman modern ini sudah semakin pesat.

Semakin berkembangnya zaman semakin canggih juga teknologi yang dihasilkan.

Hal ini membuat manusia semakin dimudahkan dengan adanya alat-alat teknologi yang canggih untuk membantu dalam menyelesaikan pekerjaan seharihari. Berkembangnya teknologi saat ini tidak hanya membawa dampak positif bagi kehidupan masyarakat, melainkan juga membawa dampak negative. Contohnya saja untuk dampak negatifnya manusia semakin malas untuk bersosialisasi dengan lingkungan sekitar karena berkembangnya social media di internet. Selain itu dengan berkembangnya era digital saat ini kita perlu mengambil sikap yang bijaksana dalam penggunaannya agar dapat memberikan manfaat bagi kehidupan kita.

\section{A. Pengertian Era Digital \\ Era digital merupakan suatu} masa di mana sebagian besar masyarakat pada era tersebut menggunakan sistem 
digital dalam kehidupan sehari-harinya. Menurut Communication Technology Timeline yang dikutip Dan Brown, berbagai jenis media elektronik di dunia mulai merebak pada awal tahun 1880an dimulai dengan alat komunikasi telepon, tape-recorder, radio. Barang elektronik lainnya seperti televisi, TV kabel, telepon selular baru mulai digunakan oleh banyak masyarakat sekitar tahun 1940 - 1970an. Teknologi komunikasi dari media elektronik pada awalnya masih menggunakan sistem analog, dan baru beralih ke sistem digital dengan ditandai hadirnya transformasi produk media seperti e-book, internet, koran digital, elibrary, e-shop dsb. Masa ini juga sering disebut sebagai revolusi digital. Revolusi digital ini telah dimulai pada awal tahun 1990an di dunia. Dengan mengingat prinsip-prinsip sistem digital tadi, maka era digital merupakan era di mana aliran informasi melalui media-media komunikasi bersifat jelas, akurat dan cepat.

Perkembangan teknologi digital adalah merupakan perkembangan dimana mulai hadirnya komputer, lahirnya internet, ponsel (telephon selular), dan juga jejaring sosial. Diantara contoh perangkat digital antara lain televisi, perrangkat permainan genggam, jam digital, telephon pintar (smartphone), komputer dan laptop. Sedangkan merupakan contoh konversi teknologi diantaranya perubahan buku-buku cetak menjadi buku elektronik (E-Book), surat menjadi Surat Elektronik (Email/Gmail), mesin ketik menjadi komputer, telepon menjadi ponsel (telephone seluler), gramaphone menjadi kaset kemudian CD (Compact Disk) kemudian beralih kepada MP3/MP4, dan jam analog menjadi jam digital kemudian Smartwatch.

Era digital yang kini telah menjadi bagian kehidupan keseharian masyarakat, khususnya generasi muda memang akan mengubah pola kehidupan. Termasuk pola belajar dan pola penyebaran informasi. Era kertas pelan tetapi pasti akan tergeser. Ketika kamus digital dapat diperoleh dengan mudah dan murah, misalnya dapat dimasuk ke dalam HP, maka kamus tercetak akan terancam. Jika memerlukan terjemahan dapat membuka "Pocket Dict" di HP. Baru jika tidak memadai kemudian mencari kamus tercetak.

Seiring dengan kemajuan teknologi, ketika kemampuan HP semakin baik dan jenis kamus digital makin lengkap, maka pocket dict akan menjelma menjadi semacam kamus bahasa Arab yang sekarang banyak dipakai, namun dalam versi digital (Application/software). Jika itu terjadi, dapat dipastikan tidak banyak lagi orang 
memerlukan kamus bahasa tercetak. Bukankah kamus digital lebih murah dan lebih fleksibel penggunaanya.

Tidak hanya itu. Setahap demi setahap, jurnal, majalah, buku dan bahkan koran juga akan digeser oleh versi digital. Jurnal ilmiah yang biasanya mahal karena jumlah cetakannya tidak banyak, kini sudah mulai beralih ke bentuk digital. Perpustakaan dengan senang berlangganan jurnal online karena murah dan tidak memakan tempat. Hampir semua koran sekarang sudah punya versi online. Dan buku teks juga sudah mulai ke versi digital. Jika itu terjadi, maka penyebaran informasi benar-benar melalui versi baru yaitu digitalisasi informasi.

\section{B. Peranan Perkembangan Teknologi pada Era Digital}

Berbicara tentang kemajuan teknologi yang pada hal ini lebih terfokus kepada media sosial, tentu memiliki dampak yang positif dan negatif dari perkembangannya tersebut. Diantara dampak positif yang bisa di dapat adalah

1. Sebagai media penyebaran informasi maupun komunikasi.

Informasi yang up to date sangat mudah menyebar melalui situs jejaring sosial. Hanya dalam tempo beberapa menit setelah kejadian, kita telah bisa menikmati informasi tersebut. Ini sangatlah bermanfaat bagi kita sebagai manusia yang hidup di era digital seperti sekarang ini. Cakrawala dunia serasa berada dalam sentuhan jari kita. Genggaman tangan saja.

2. Sebagai sarana untuk mengembangkan keterampilan, kreativitas dan sosial

Mengasah keterampilan teknis dan sosial merupakan kebutuhan yang wajib dipenuhi agar bisa bertahan hidup dan berada dalam neraca persaingan diera modern seperti sekarang ini. Hal ini sangatlah penting, tidak ada batasan usia, semua orang butuh untuk berkembang.

3. Memperluas jaringan pertemanan Dengan menggunakan jejaring sosial, kita bisa berkomunikasi dengan siapa saja, bahkan dengan orang yang belum kita kenal sekalipun dari berbagai penjuru dunia. Kelebihan ini bisa kita manfaatkan untuk menambah wawasan, bertukar pikiran, saling mengenal budaya dan ciri khas daerah masing-masing, dll. Hal ini dapat pula mengasah kemampuan berbahasa seseorang. Misalnya, belajar bahasa Arab dengan 
memanfaatkan fasilitas call atau video call yang disediakan di situs jejaring sosial.Beberapa dampak positif dari media sosial tersebut sangatlah berguna bagi kehidupan di masa sekarang. Dimana media sosial yang sudah ada sangat bisa di kembangkan sesuai dengan kebutuhan masing-masing dan sangat berguna apabila digunakan sebagai mestinya dan tidak melakukan pelanggaran yang dapat merugikan orang lain.Namun dengan adanya media sosial tidak hanya menimbulkan dampak positif bagi kehidupan sosial masyarakat. Perkembangan tersebut juga mempunyai dampak negatif diantaranya :

4. Pembelajaran Jarak jauh Tentunya dengan semakin mudahnya akses informasi dan tanpa membatasi ruang dan waktu, hal ini tentu dapat digunakan pula dalam proses pembelajaran, dimanapun pendidik dan pseserta didik berada selama berada pada jangkauan teknologi tersebut diantaranya internet maupun smartphone ataupun lapotop, maka pembelajaran bukan lagi merupakan suatu hambatan.
5. Kejahatan dunia maya (cyber crime)

Seiring berkembangnya teknologi, berkembang pula kejahatan. Didunia internet, kejahatan dikenal dengan nama cyber crime. Kejahatan dunia maya sangatlah beragam. Diantaranya, carding, hacking, cracking, phising, dan spamming.

6. Melemahkan dan menurunkan sensitifitas

Penurunan sensitifitas
yang dimaksud disini adalah
menurunnya tingkat simpati dan
empati seseorang terhadap dunia
nyata. Dengan jejaring sosial,
seseorang cenderung melupakan
dunia nyata dan tenggelam
didalam dunia maya.
Merenggangkan dan mengabaikan
sesuatu yang terjadi disekitarnya
dan lebih memilih untuk
memperhatikan sesuatu yang
terjadi didunia maya.

C. Pengertian bahasa

Bahasa adalah sistem lambang bunyi yang arbitrer, yang digunakan oleh anggota suatu masyarakat untuk bekerja sama, berinteraksi, dan mengidentifikasikan 
diri ${ }^{1}$ Ibnu Manzhur dalam Lisan alArab, mendefinisikan bahasa dengan:
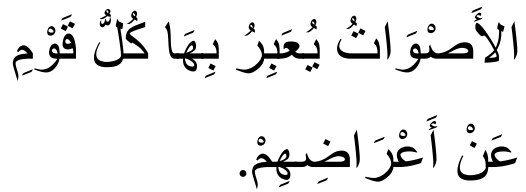

(berbagai bunyi yang digunakan masyarakat untuk mengungkapkan berbagai maksud atau tujuan mereka) ${ }^{2}$

Kebanyakan orang belajar lebih dari satu bahasa. Seseorang mungkin dapat mengetahui atau belajar dua bahasa atau lebih dari permulaan hidupnya. Yang lebih terbiasa ialah bahwa dia belajar bahasa kedua atau bahasa asing sesudah sistem bahasa pertamanya mantap.

Oleh karena kajian bahasa tidak cukup dengan mengenali ciriciri konstruksi bahasa, tetapi ia harus lengkap dengan mengenali fungsi dalam kerangka masyarakat. Maka seseorang yang ingin mempelajari bahasa kedua atau bahasa asing dituntut untuk memiliki keterampilan-keterampilan berbahasa, yang mana keterampilan ini dapat dia kembangkan dan kuasai

\footnotetext{
${ }^{1}$ http://pusatbahasa.diknas.go.id/kbbi

${ }^{2}$ Ibnu Manzhur, , Lisan Al-Arab (huruf Al wau-Alya, entri lagha), Darash-Shadir, h. 250
}

sesuai dengan motivasinya dalam mempelajari bahasa keduanya.

Bahasa mencakup setiap sarana komunikasi dengan menyimbolkan pikiran dan perasaan untuk menyampaikan makna kepada orang lain. Termasuk didalamnya perbedaan bentuk komunikasi yang luas seperti: tulisan, bicara, bahasa symbol, ekspresi muka, isyarat, dan seni. Bicara adalah bentuk bahasa yang menggunakan artikulasi atau kata-kata yang digunakan untuk menyampaikan maksud. Karena bicara merupakan bentuk komunikasi yang paling efektif, penggunaannya paling luas dan paling penting. Berbicara merupakan alat komunikasi terpenting dalam berkelompok. Anak belajar bagaimana berbicara dengan baik dalam berkomunikasi dengan orang lain. Bertambahnya kosakata yang berasal dari berbagai sumber menyebabkan semakin banyak perbendaharaan kata yang dimiliki. Anak mulai menyadari bahwa komunikasi yang bermakna tidak dapat dicapai bila anak tidak mengerti apa yang dikatakan oleh orang lain. Hal ini mendorong anak untuk meningkatkan pengertiannya. ${ }^{3}$

${ }^{3}$ John W. Santrock, Perkembangan Anak, Jakarta: Erlangga, 2007, Hlm 362. 
Belajarberbahasa merupakan aktivitas individu yang menghasilkan pengalaman tertentu yang menentukan kualitas perunahan tingkah laku (behaviorchange) pada individu pelajar, dan perubahan tersebut mengarah pada kematangan. ${ }^{4}$

D. Perkembangan bahasa anak

Pengertian perkembangan atau dalam bahasa inggrisnya development merupakan suatu proses yang pasti dialami setiap individu, perkembangan ini adalah bersifat kualitatif dan berhubungan dengan kematangan serta sistematis. $^{5}$

Syamsu Yusuf dalam bukunya mendefinisikan perkembangan sebagai perubahan yang progress dan kontinyu dalam diri individu dari mulai lahir sampai mati. Yang mana aspek-aspek dari perkembangan meliputi : fisik, intelegensi, emosi, bahasa, sosial, kepribadian, moral dan kesadaran beragama. $^{6}$

${ }^{4}$ Brown, H.Duglas. 1980. Principle of Language Learning and Teaching. PrenticeHall.New Jersey.

${ }^{5}$ John W. Santrock, Life Span Development: Perkembangan Masa Hidup, Edisi 5 jilid 1, Jakarta: ErlanggaH. 362

${ }^{6}$ Yusuf, Syamsu. 2005. Psikologi Perkembangan Anak dan Remaja.Bandung : Rosdakarya.

${ }^{6}$ Tarigan dkk., Djago dkk. 1998. Pendidikan Bahasa dan Sastra Indonesia di Kelas Rendah
Perkembangan bahasa adalah suatu proses perkembangan pada anak yang mencakup aspek reseptif dan ekspresif. Aspek bahasa reseptif adalah kemampuan untuk mengerti apa yang dilihat dan apa yang didengar. Bahasa ekspresif adalah kemampuan berkomunikasi secara simbolik baik visual maupun auditorik. ${ }^{7}$

Perkembangan bahasa anak itu dipengaruhi oleh bakat bawaan, lingkungan atau faktor lain yang menunjang, yaitu perkembangan fisik dan intelektual. Kemampuan berbahasa sangat penting bagi anak-anak karena anak-anak akan dapat mengembangkan kemampuan sosialnya melalui berbahasa. Keterampilan bergaul dalam lingkungan sosial dimulai dengan penguasaan kemampuan berbahasa. Melalui bahasa, anak dapat mengekspresikan pikiran, sehingga orang lain memahaminya dan menciptakan suatu hubungan sosial. Jadi, tidaklah mengherankan bahwa bahasa dianggap sebagai salah satu indikator kesuksesan seorang anak. ${ }^{8}$

Berbagai pendapat tentang teori pengembangan bahasa dikemukakan oleh

\footnotetext{
${ }^{7}$ HartantoF,SelinaH,FitraS.PengaruhPer kembangan Bahasa Terhadap Perkembangan Kognitif Anak Usia 1-3Tahun. Sari Pediatr. 2011;12:1-5.

${ }^{8}$ Tarigan dkk., Djago dkk. 1998. Pendidikan Bahasa dan Sastra Indonesia di Kelas Rendah. Jakarta: Depdikbud.
} 
para ahli. Pemahaman akan berbagai teori pengembangan bahasa dapat memengaruhi penerapan metode implementasi terhadap pengembangan bahasa anak.

Kaum behaviorisme menerangkan bahwa proses pemerolehan bahasa pertama dikendalikan dari luar diri si anak, yaitu oleh rangsangan yang diberikan melalui lingkungan. Istilah bahasabagi kaum behaviorisme dianggap kurang tepat karenan istilah bahasa itu menyiaratkan suatu wujud, sesuatu yang dimiliki atau digunakan, dan bukan sesuatu yang dilakukan. Padahal bahasa itu merupakan salah satu perilaku, di antara perilaku-perilaku manusia lainnya. Menurut kaum behaviorisme kemempuan berbicara dan memehami bahasa oleh anak diperoleh melalui rangsangan dari lingkungannya. Anak dianggap sebagai penerima pasif dari tekanan lingkungannya, tidak memiliki peranan yang aktif di dalam proses perkembangan perilaku verbalnya. Bahkan kaum behaviorisme tidak mengakui kematangan anak dalam pemerolehan bahasa. Kaum behaviorisme tidak mengakui pandangan bahwa anak menguasai kaidah bahasa dan memiliki kemempuan untuk mengabstrakkan cirriciri penting dari bahasa di lingkungannya. Mereka berbendapat rangsangan (stimulus) dari lingkungan tertentu memperkuat kemempuan berbahasa anak. Perkembangan bahasa mereka pandang sebagai suatu kemajuan dari pengungkapan verbal yang berlaku secara acak sampai ke kemampuan yang sebenarnya untuk berkomunikasi memalui prinsip pertalian $\mathrm{S}-\mathrm{P}$ (stimulus - respon) dan proses peniruan-peniruan. ${ }^{9}$

Skinner, mendefinisikan bahwa pembelajaran dipengaruhi oleh perilaku yang dibentuk oleh lingkungan eksternalnya, artinya pengetahuan merupakan hasil dari interaksi dengan lingkungannya melalui pengondisian stimulus yang menimbulkan respons. Perubahan lingkungan pembelajaran dapat memengaruhi pikiran, perasaan, dan perilaku anak secara bertahap. Perilaku positif pada anak cenderung akan diulang ketika mendapat dorongan yang sesuai dengan kemampuan anak dari lingkungannya. Latihan untuk anak harus menggunakan bentuk-bentuk pertanyaan (stimulus) dan jawaban (respons) yang dikenalkan secara bertahap, mulai dari yang sederhana sampai pada yang lebih rumit.

E. Faktor-faktor yang mempengaruhi perkembangan bahasa anak

\footnotetext{
${ }^{9}$ Chear, Abdul. 2002. Psikolinguistik kajian Teori. Jakarta. Rineka Cipta
} 
Secara rinci dapat

diidentifikasi sejumlah faktor yang mempengaruhi perkembangan bahasa, yaitu:

1. Kognisi (Proses Memperoleh Pengetahuan)

Tinggi rendahnya kemampuan kognisi individu akan mempengaruhi cepat lambatnya perkembangan bahasa individu. Ini relevan dengan pembahasan sebelumnya bahwa terdapat korelasi yang signifikan antara pikiran dengan bahasa seseorang.

2. Pola Komunikasi Dalam Keluarga

Dalam suatu keluarga yang pola komunikasinya banyak arah akan mempercepat perkembangan bahasa anak dalam keluarganya. Karena interkasi yang terjalin tidak terbatas.

3. Jumlah Anak Atau Jumlah Keluarga

Suatu keluarga yang memiliki banyak anggota keluarga, perkembangan bahasa anak lebih cepat, karena terjadi komunikasi yang bervariasi dibandingkan dengan yang hanya memiliki anak tunggal dan tidak ada anggota lain selain keluarga inti.

4. Posisi Urutan Kelahiran

Perkembangan bahasa anak yang posisi kelahirannya di tengah akan lebih cepat ketimbang anak sulung atau anak bungsu. Hal ini disebabkan anak sulung memiliki arah komunikasi ke bawah saja dan anak bungsu hanya memiliki arah komunikasi ke atas saja.

5. Kedwibahasaan(Pemakaian dua bahasa)

Anak yang dibesarkan dalam keluarga yang menggunakan bahasa lebih dari satu atau lebih bagus dan lebih cepat perkembangan bahasanya ketimbang yang hanya menggunakan satu bahasa saja karena anak terbiasa menggunakan bahasa secara bervariasi. Misalnya, di dalam rumah dia menggunakan bahasa sunda dan di luar rumah dia menggunakan bahasa Indonesia. Dalam bukunya "Psikologi Perkembangan Anak dan Remaja" Syamsu Yusuf mengatakan bahwa perkembangan bahasa dipengaruhi oleh 5 faktor, yaitu: faktor kesehatan, intelegensi, 
statsus sosial ekonomi, jenis kelamin, dan hubungan keluarga.

\section{Karakteristik}

perkembangan bahasa remaja sesungguhnya didukung oleh perkembangan kognitif yang menurut Jean Piaget telah mencapai tahap operasional formal. Sejalan dengan perkembangan kognitifnya, remaja mulai mampu mengaplikasikan prinsip-prinsip berpikir formal atau berpikir ilmiah secara baik pada setiap situasi dan telah mengalami peningkatan kemampuan dalam menyusun pola hubungan secara komperhensif, membandingkan secara kritis antara fakta dan asumsi dengan mengurangi penggunaan symbol-simbol dan terminologi konkret dalam mengomunikasikannya.

\section{F. Pengaruh Era digital terhadap} perkembangan bahasa anak

Perkembangan teknologi pada zaman modern ini sudah semakin pesat. Semakin berkembangnya zaman semakin canggih juga teknologi yang dihasilkan. Hal ini membuat manusia semakin dimudahkan dengan adanya alat-alat teknologi yang canggih untuk membantu dalam menyelesaikan pekerjaan seharihari. Berkembangnya teknologi saat ini tidak hanya membawa dampak positif bagi kehidupan masyarakat, melainkan juga membawa dampak negative. Contohnya saja untuk dampak negatifnya manusia semakin malas untuk bersosialisasi dengan lingkungan sekitar karena berkembangnya social media di internet. Selain itu dengan berkembangnya era digital saat ini kita perlu mengambil sikap yang bijaksana dalam penggunaannya agar dapat memberikan manfaat bagi kehidupan kita. Agar tidak Banyak manusia yang justru terjebak dalam peranan kemunculan digital yang menjadikan manusia menjadi tidak manusiawi seperti menurun bahkan hilangnya etika, moral, sosial dan budaya.

Anak-anak belajar berkomunikasi dengan orang lain lewat berbagai cara. Meskipun cara anak yang satu dengan yang lain berbeda, ada halhal yang umum yang terjadi pada hampir setiap anak. Pengetahuan tentang hakikat perkembangan bahasa anak, perkembangan bahasa lisan dan tulis yang terjadi pada mereka, dan perbedaan individual dalam pemerolehan bahasa sangat penting bagi pelaksanaan pembelajaran bahasa anak. 
Proses belajar generasi digital adalah dengan selalu mengakses dengan google, yahoo, atau mesin pencari lainnya. Kemampuan belajar mereka jauh lebih cepat karena segala informasi terdapat diujung jari mereka. Namun hal ini pula dapat menjadi kekhawatiran bagi para orangtua maupun pendidik apabila digunakan untuk mengakses seusatu yang dapat merusak moral mental anak sehingga berdampak pula pada intelejensianya.

Sebuah Era, dimana, jarak tak lagi menjadi penghambat, guru dan kelas bukan lagi satu-satunya. Digit, menjadi penentu keberhasilan, dalam banyak hal; bisnis, politik, pendidikan demikian juga pembelajaran bahasa. Era ini, sudah tidak mampu dibendung dengan kekuatan apapun. bagaimana dimana-mana sekarang manusia, sudah menjadikan WhatsApp (WA), Facebook (FB), Tweeter (TW), sebagai teman 24 jam. Jaringan internet, sudah paling dicari, kehilangan sinyal seperti kehilangan anak, teman dan orang yang dicintai.

Namun terdapat hal positif pula yang dapat disikapi pada era digital saat ini,adalah terdapat banyak jenis stimulasi yang bisa digunakan untuk memicu perkembangan bahasa anak. The American Academy of Pediatric menjelaskan bahwa paparan terhadap media seperti televisi, film, video, games, internet, lirik musik, koran, majalah, buku dan iklan sangat besar potensinya untuk dapat memicu adanya gangguan kesehatan namun disisi lain media juga bisa membawa efek positif di kehidupan anak maupun dewasa. ${ }^{10}$

$\begin{array}{ccr} & \text { Revoluasi digital ditandai } \\ \text { dengan } & \text { kemampuan } & \text { untuk }\end{array}$
mentranspormasikan semua bentuk informasi, teks, grafik, suara, gambar, statistik, dan gambar digital yang bergerak. Maka, guru dapat menggunakannya, sebagai media pembelajaran bahasa Arab, yang; efektif, aktif, kreatif dan menyenangkan. Dan guru dapat juga memanfaatkan ELearning dan blog, untuk meningkatkan empat maharah dan melatihnya secara terus menerus dan terukur.

Berdasarkan penelitian, media interaktif memegang peranan yang cukup penting dalam proses pemberian stimulasi karena media ini dapat memperlancar pemahaman serta memperkuat ingatan anak. Media inter aktif merupakan salah satu jenis media yang banyak digunakan, media tersebut bukan hanya memberikan informasi atau pendidikan tentang suatu hal

\footnotetext{
${ }^{10}$ Principles $\quad$ O. PolicyStatementMediaEducation abstract.Am Acad Pediatr. 2010;126. doi:10.1542/peds.2010-1636.
} 
namun mengemasnya dengan unsur yang menghibur. Unsur gambar, suara, animasi, dan video ditampilkan didalamnya agar suasana menjadi lebih inter aktif dan tidak membosankan bagianak.

Bahasa merupakan kemampuan untuk berkomunikasi dengan orang lain. Bahasa merupakan faktor hakiki yang membedakan manusia dengan hewan. Bahasa erat kaitannya dengan perekembangan berfikir individu. Perkembangan berfikir individu tampak dalam perkembangan bahasanya yaitu kemampuan membentuk pengertian, menyusun pendapat dan menarik kesimpulan. Sedangkan, perkembangan merupakan suatu proses yang pasti dialami setiap individu, perkembangan ini adalah bersifat kualitatif dan berhubungan dengan kematangan serta sistematis. Perkembangan bahasa pada anak sangatlah penting karena melalui bahasa, anak dapat mengekspresikan pikiran, sehingga orang lain memahaminya dan menciptakan suatu hubungan sosial. Jadi, tidaklah mengherankan bahwa bahasa dianggap sebagai salah satu indikator kesuksesan seorang anak.

Penelitian telah menunjukkan bahwa penggunaan media digital bisa menunda perkembangan bahasa anak, terutama untuk anak-anak usia 2 tahun dan dibawahnya. Namun pemanfaatan media digital secara tepat guna dan sesuai sasaran sebaliknya dapat pula meningkatkan kemampuan bahasa anak. Seperti bentuk audio untuk menambah kosa anak Memanfaatkan media digital dalam bentuk kata, angka, dan lagu-lagu. E-book bahasa dan aplikasi-aplikasi latihan belajar bahasa lainnya, Sehingga menjadikan anak lebih merasa senang dan tertarik dalam mengembangkan dan mempelajari bahasa khususnya bahasa keduanya.

Media inter aktif dalam penggunaannya harus memperhatikan usia anak. Menurut Council Communication and Mediao fAmerican Academy of Pediatric, penggunaan media pada anak usia dibawah 2 tahun secara signifikan membawa dampak negatif pada perkembangan anak. Anak yang memulai menggunakan media pada usia 2 sampai 3 tahun memberikan dampak yang lebih baik pada tes kemampuan bahasa dibandingkan anak yang mulai menggunakan media saat usia4 sampai dengan 5 tahun. ${ }^{11}$

Penelitian yang dilakukan Oleh Guernsey pada tahun 2012 memaparkan

\footnotetext{
${ }^{11}$ SheniaA. Buku Pintar Menguasai Multimedia.1sted. (Sopian,ed.). Jakarta: mediakita; 2009.
} 
bahwa syarat media yang baik untuk anak yaitu harus memerhatikan 3 Cyaitucontent, contextandchild. ${ }^{12}$

Sedangkan menurut American Academy of Pediatric syarat media yang baik untuk anak diantaranya digunakan pada anak lebih dari 2 tahun, pendampingan orang dewasa saat penggunaan dan paparan dalam sehari tidak lebih dari 2 jam. ${ }^{13}$ Media inter aktif memiliki efek positif pada perkembangan bahasa anak jika dilakukan berdasarkan anjuran yang telah ditetapkan dalam penggunaannya. Mark Prensky dalam bukunya yang berjudul "Don'tbother meMum. I'mlearningnow!" menjelaskan bahwa media interaktif pada anak dapat berefek dalam perkembangan bahasa anak dalam meningkatkan konsentrasi, mengasosiasikan kata dan symbol dengan objek, diskriminasi, identifikasi persamaan dan perbedaan, mengklasifikasi objek, melihat ada tidaknya hubungan, mengembangkan konsep bentuk ukuran dan ruang, meningkatkan rasa keingin tahuan, serta menggunakan kreatifitas anak. ${ }^{14}$

\footnotetext{
${ }^{12}$ GuernseyL. Electronic Media and Language Development-03.pdf.NewAmFound.2013:11-17.

${ }^{13}$ Principles O. Policy StatementMedia Education abstract. Am Acad Pediatr. 2010;126. doi:10.1542/peds.2010-1636.

${ }^{14}$ CurriculumV,AuthorityA.DISCUSSI ONPAPER-TELEVISION, DIGITAL MEDIA AND CHILDREN'SLEARNING.VCAA. 2008:126.
}

Semakin banyak bentuk stimulus yang diterima maka anak akan lebih mudah memahami hal tersebut karena pada media inter aktif ini anak menerima 3 jenis stimulus yaitu visio-motor dan auditorik. Selain itu penyajian dari media inter aktif yang menampilkan simbol simbol yang sesuai dengan kehidupan nyata akan meningkatkan kemampuan mengingat pada anak.

\section{Daftar Pustaka}

Chear, Abdul. 2002. Psikolinguistik kajian Teori. Rineka Cipta: Jakarta.

$\begin{array}{rr}\text { Curriculum VuthorityA. } & \text { Aut } \\ \text { DISCUSSION } & \text { PAPER- } \\ \text { TELEVISION, } & \text { DIGITAL } \\ \text { MEDIA AND CHILDREN' } & \text { CHEARNING. VCAA. } 2008\end{array}$

GuernseyL. Electronic Media and Language Development-03.pdf.NewAmFound. 2013

https://archive.org/stream/BukuSakuMen didikAnakDiEraDigitalEdLina.p df/Buku\%20Saku\%20Mendidik \%20Anak\%20Di\%20Era\%20Di gital-edLina.pdf_djvu.txt

http://pusatbahasa.diknas.go.id/kbbi

https://bulelengkab.go.id/assets/instansik ab/51/bankdata/e-book-materibimtek-mendidik-anak-di-eradigital-29.pdf

John W. Santrock, Perkembangan Anak, Jakarta: Erlangga, 2007

Manzhur, Ibnu, Lisan Al-Arab (Huruf AlWau-Al-Ya, Entri Lagha), Dar Ash-Shadir-Beirut, T.T. Juz 15

Principles O. PolicyStatement- Media Education abstract.Am Acad 
Pediatr. $\quad 2010 \quad ; 126$.

doi:10.1542/peds.2010-1636.

Tarigan dkk., Djago dkk. 1998.

Pendidikan Bahasa dan Sastra

Indonesia di Kelas Rendah.

Jakarta: Depdikbud. 